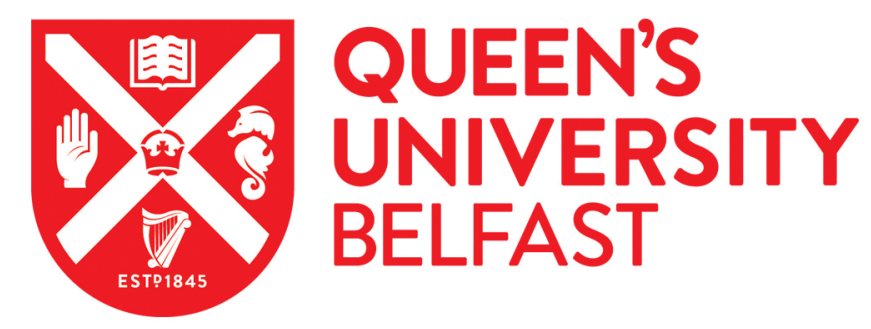

\title{
Inter-Agency Evidence Sharing in Competition Law Enforcement
}

Martyniszyn, M. (2015). Inter-Agency Evidence Sharing in Competition Law Enforcement. International Journal of Evidence and Proof, 19(1), 11-28. https://doi.org/10.1177/1365712714561190

Published in:

International Journal of Evidence and Proof

Document Version:

Peer reviewed version

Queen's University Belfast - Research Portal:

Link to publication record in Queen's University Belfast Research Portal

Publisher rights

Copyright 2015 the author

\section{General rights}

Copyright for the publications made accessible via the Queen's University Belfast Research Portal is retained by the author(s) and / or other copyright owners and it is a condition of accessing these publications that users recognise and abide by the legal requirements associated with these rights.

Take down policy

The Research Portal is Queen's institutional repository that provides access to Queen's research output. Every effort has been made to ensure that content in the Research Portal does not infringe any person's rights, or applicable UK laws. If you discover content in the Research Portal that you believe breaches copyright or violates any law, please contact openaccess@qub.ac.uk. 


\title{
INTER-AGENCY EVIDENCE SHARING \\ IN COMPETITION LAW ENFORCEMENT
}

\author{
MAREK MARTYNISZYN*
}

Abstract:

While transnational antitrust enforcement is becoming only more common, the access to foreign-based evidence remains a considerable practical challenge. This article appraises considerations and concerns surrounding confidentiality, and looks into ways of their possible accommodation. It further identifies and critically evaluates the existing mechanisms allowing for inter-agency confidential information/ evidence sharing in competition law enforcement. The article outlines the shortcomings of the current framework and points to novel unilateral approaches. In the latter regard the focus is devoted to Australia, where the competition agency is empowered to share confidential information with foreign counterparts, also without any underlying bilateral agreement and on a non-reciprocal basis. This solution shows that a pragmatic and workable approach to inter-agency evidence sharing can be achieved.

Keywords:

competition law enforcement, antitrust law enforcement, transnational enforcement, cooperation agreements, inter-agency cooperation, Multilateral Legal Assistance Treaties, MLAT, information gateways, extraterritoriality, evidence in competition cases, confidential information

Disclaimer: This is a pre-edited manuscript. The final, edited version is forthcoming in 19(1) International Journal of Evidence and Proof (2015). Please, refer to the final version.

\footnotetext{
* Lecturer in Law, Queen's University Belfast. E-mail: m.martyniszyn @qub.ac.uk. Thanks to Anca Chiriţă, John Jackson, Imelda Maher, Spencer Weber Waller, and Bruce Wardhaugh for helpful comments on earlier drafts of this article. The author gratefully acknowledges the comments by the anonymous reviewers of the IJEP. The usual disclaimer applies.
} 
Growing economic interconnectedness is a feature of the global business landscape. ${ }^{1}$ Transnational commerce grows, even if at a slowed pace as compared to its pre-recession dynamic. ${ }^{2}$ At the same time, there is no World Competition Court. Private anticompetitive conduct is not regulated within any broad, multilateral framework. Competition laws remain predominantly national. ${ }^{3}$ Extraterritoriality is the only tool of general availability allowing addressing anticompetitive harm caused by foreign entities operating abroad. ${ }^{4}$ From this perspective the major practical challenge in enforcementoften the crux of the matter-is the issue of accessing foreign-based evidence.

Most antitrust proceedings outside the US are not judicial, but administrative in nature. This means that in transnational enforcement, rules of inter-agency cooperation (that is, cooperation between agencies/ authorities of different regimes enforcing competition rules) are of greater practical significance than the means of international judicial cooperation. ${ }^{5}$ That said, the majority of existing cooperation agreements do not allow for sharing of confidential information, or providing assistance in obtaining evidence, ${ }^{6}$ despite the fact that 'accessing relevant information is the lifeblood of competition enforcement' ${ }^{7}$

\footnotetext{
${ }^{1}$ For detailed data on economic globalization see KOF Index of Globalization, $<$ http://globalization.kof.ethz.ch/>.

${ }^{2}$ For some general thoughts on what type of challenges face multinational companies in the aftermath of the recent crisis see Ernst \& Young, 'Looking Beyond the Obvious: Globalization and New Opportunities for Growth' (January 2013), <http://www.ey.com/Publication/vwLUAssets/Globalization__Looking_beyond_the_obvious/\$FILE/LookingBeyondObvious.pdf $>$.

${ }^{3}$ The terms antitrust and competition law are used in this article interchangeably.

${ }^{4}$ See generally on extraterritoriality Menno T. Kamminga, 'Extraterritoriality' [in:] Rüdiger Wolfrum (ed.), The Max Planck Encyclopedia of Public International Law, online ed. (Oxford University Press, 2010), $<$ http://www.mpepil.com/>. For the discussion in the antitrust context see, for example, Eleanor M. Fox, 'Can we Solve the Antitrust Problems of Globalization by Extraterritoriality and Cooperation? Sufficiency and Legitimacy', 48(2) Antitrust Bulletin 355 (2003).

${ }^{5}$ Jürgen Basedow, 'Competition Policy in a Globalized Economy: from Extraterritorial Application to Harmonization' in Manfred Neumann and Jürgen Weigand (eds), The International Handbook of Competition (Cheltenham: Edward Elgar, 2004) 325.

${ }^{6}$ For the analysis of enforcement cooperation agreements see Anestis S. Papadopoulos, The International Dimension of EU Competition Law and Policy (Cambridge: CUP, 2010) 52-82. See further, International Enforcement Co-operation: Secretariat Report on the OECD/ICN Survey on International Enforcement Co-operation (2013), 19, 119-140, <http://www.oecd.org/competition/InternEnforcementCooperation2013.pdf >.

${ }^{7}$ Brendan J. Sweeney, The Internationalisation of Competition Rules (London: Routledge, 2010) 279.
} 
While international cooperation in the field of antitrust is overall a success story, the 'worst part of the track record"8 — as Judge Wood put it—is the lack of the development of inter-agency enforcement cooperation. This relates primarily to the very issue of information and evidence sharing, despite the numerous calls for greater collaboration in this regard. ${ }^{9}$ In fact, in the recent international enforcement cooperation survey conducted by the Competition Committee of the Organization for Economic Cooperation and Development (OECD) many competition agencies acknowledged that legal limits preventing them from exchanging confidential information and evidence are the primary impediment to international cooperation. ${ }^{10}$

Given the limitations of the international judicial assistance and the territorial nature of enforcement jurisdiction under international law, ${ }^{11}$ the information sharing between competition authorities has an important role to play in narrowing down the existing enforcement gap. By enabling access to foreign-based evidence, such cooperation improves the effectiveness of reliance on extraterritorial application of domestic competition law. ${ }^{12}$ In the longer term it could lead - through trust building - to a more multilateral response to challenges posed by transnational anticompetitive conduct.

This article offers an original contribution to the existing literature by identifying and critically evaluating the existing mechanisms allowing for inter-agency confidential

\footnotetext{
${ }^{8}$ Diane P. Wood, 'Soft Harmonizing among Competition Laws: Track Record and Prospects', 48 Antitrust Bulletin 305 (2003), at 315-16.

${ }^{9}$ For example, within the OECD framework. See OECD, 'Hard Core Cartels. Recent Progress and Challenges Ahead', 44, 47 (2003). The case of merger review is somewhat different, since it is quite natural for merging parties to grant confidentiality waivers, allowing competition agencies to share and discus the submitted information, facilitating the review. For discussion of confidentiality waivers in this context and sample waivers forms see International Competition Network, 'Model Confidentiality Waiver' (2005), <http://www.internationalcompetitionnetwork.org/uploads/library/doc330.pdf>.

${ }^{10}$ International Enforcement Co-operation: Secretariat Report on the OECD/ICN Survey on International Enforcement Co-operation, above note 6, at 22-23.

${ }^{11}$ Although the practices of states vary, the conservative view holds that under international law it is permitted merely to notify a foreign party in a foreign state about the proceedings in the forum. No command could be addressed to such a party; no threat of penalties for non-compliance can be imposed. See generally Frederick Alexander Mann, 'The Doctrine of Jurisdiction in International Law', 111 Recueil des Cours 1, ch. IV (1964).

${ }^{12}$ Apart from that key effect, such cooperation helps to avoid contradictory outcomes and allows for more efficient allocation of scarce resources of agencies (by, for example, allowing to avoid duplication). This is particularly so when cooperating authorities investigate the same conduct.
} 
information/ evidence sharing in competition law enforcement. It outlines the shortcomings of the current regulatory framework and points to novel unilateral approaches. In the latter regard the focus is devoted to Australia, where the competition agency is empowered to share confidential information with foreign counterparts even without any underlying bilateral agreement and also on a non-reciprocal basis. This solution shows that a pragmatic and workable approach to inter-agency evidence sharing can be achieved.

Part I of this article restates and appraises considerations and concerns surrounding confidentiality, both in general and specifically from a competition law perspective. It also explores ways of their possible accommodation. Part II offers an overview of rules on confidentiality applicable to antitrust enforcement in the EU and in the US- two most influential competition law regimes. Part III identifies and evaluates the existing international (bilateral and plurilateral) and domestic instruments enabling sharing of confidential information between antitrust agencies. The conclusions call for following the Australian unilateral good practice - enabling, but not requiring, domestic agencies to share confidential information with foreign counterparts on a case-by-case basis and subject to necessary and appropriate safeguards.

\section{CONSIDERATIONS SURROUNDING CONFIDENTIALITY AND EVIDENCE SHARING}

The laws guarding confidentiality remain a considerable obstacle in furthering interagency cooperation in competition law enforcement. There are various, often important, reasons why certain types of information should be kept confidential. This part 
identifies the most commonly voiced concerns against inter-agency cooperation in this regard, looks into their validity and possible ways of their accommodation. ${ }^{13}$

Firstly, it is often argued that the need to protect business secrets, commercially/business sensitive information requires stringent rules on confidentiality. Business plans and strategies are of paramount importance from a firm's perspective. Exchanges between agencies may lead to information being 'leaked' to companies in foreign jurisdictions for their benefit. ${ }^{14}$ In response to this argument the US Department of Justice (DoJ) invited the business community to identify a case in which confidential business information shared between competition authorities has been misused or leaked to foreign competitors. So far no example has been identified. ${ }^{15}$

Secondly, it is claimed that exchange of evidence between authorities could undermine leniency programmes. Many antitrust agencies introduced programmes which allow cartel members, especially whistleblowers, to benefit either from full or partial immunity ${ }^{16}$ in exchange for reporting prohibited conduct and helping the agency investigate it. ${ }^{17}$ Apart from the effects in particular cases, leniency programmes are a significant factor in destabilizing cartels and deterring their formation. In the context of inter-agency information sharing the argument is that such exchanges may lead to the

\footnotetext{
${ }^{13}$ Compare Michelle Chowdhury, 'From Paper Promises to Concrete Commitments: Dismantling The Obstacles to Transatlantic Cooperation in Cartel Enforcement', 13-20 (AAI Working Paper No. 11-09, 2011), <http://www.antitrustinstitute.org/ antitrust/sites/default/files/working_paper_11-09.pdf>; Sweeney, above note 7, at 300-04; Bruno Zanettin, Cooperation Between Antitrust Agencies at the International Level (Oxford: Hart Publishing, 2002) 131-45.

${ }^{14}$ Sweeney, above note 7 , at 302-04.

${ }^{15}$ Scott D. Hammond, Dispelling the Myths Surrounding Information Sharing, 6 (The ICN Cartels Workshop, Sydney 2004), <http://www.justice.gov/atr/public/speeches/206610.pdf>.

${ }^{16}$ In some regimes, for example in the South Korea, Hungary and in the UK, a whistleblower may also benefit from a qui tam reward (a cartel 'bounty'). See D. Daniel Sokol, 'Detection and Compliance in Cartel Policy', 8(2) CPI Antitrust Chronicle (2011), <http://ssrn.com/paper=1935907>; Kevin R. Sullivan, et al., 'The Potential Impact of Adding a Whistleblower Rewards Provision to ACPERA', (10) Antitrust Source 1 (2011), <http://www.americanbar.org/content/dam/aba/publishing/antitrust_source/oct11_sullivan_10_24f.authcheckdam.pdf $>$. Compare the UK's Office of Fair Trading online information on such rewards <http://www.oft.gov.uk/OFTwork/competition-act-and-cartels/cartels/rewards>.

${ }^{17}$ For example, under the EU leniency scheme an applicant may in certain circumstances benefit from full immunity from a fine. Commission Notice on Immunity from fines and reduction of fines in cartel cases, OJ C 298, 11-22 (2006), paras 8-13. On the EU and the US leniency programmes see Nicolo Zingales, 'European and American Leniency Programmes: Two Models Towards Convergence?', 5(1) Competition Law Review 5 (2008).
} 
cooperating firm being investigated in the other jurisdiction. The threat is that agencies may share inculpatory evidence. Therefore, such cooperation could undermine leniency programmes by impairing the incentives for cartels members to cooperate. ${ }^{18}$ While this is a valid consideration, appropriate safeguards can be built in the cooperation arrangements to rule out this particular risk for leniency applicants. For example, the recent EU-Switzerland Cooperation Agreement explicitly rules out sharing of information provided under leniency programmes. ${ }^{19}$ Moreover, in the EU there is no EU-wide leniency system. An application for leniency at the EU level is not an application for leniency in any of the Member States. Firms are encouraged to simultaneous submit applications to the National Competition Authorities (NCAs) in those Member States whose markets were affected by the conduct in question. ${ }^{20}$ That said, the Commission clarifies that information voluntarily submitted by an applicant will only be transmitted to an NCA with applicant's consent. ${ }^{21}$ While the current intraEU system of handling leniency applications is not free from difficulties, ${ }^{22}$ it can serve as an example of a workable multi-jurisdictional approach toward inter-agency exchange of evidence, addressing the applicants concerns. However, given the highly integrated nature of the EU, this arrangement should be learnt from with caution.

Another argument raised against inter-agency evidence sharing is that such materials may be discoverable in recipient jurisdictions (either via rules on access to evidence or under the freedom of information legislation), exposing the firms involved to private actions for damages. The threat of discoverability could further undermine leniency programmes. This seems to be the reason why the US and EU leniency programmes

\footnotetext{
${ }^{18}$ Chowdhury, above note $13,13-15$.

${ }^{19}$ See below text accompanying notes 73-78.

${ }^{20}$ Commission Notice on Cooperation within the Network of Competition Authorities, OJ C 101, 43-53 (2004), para 38.

${ }^{21}$ Consent is not required only in three narrowly defined situations, in which the applicant is assured that no sanctions will be imposed upon him by the competition authority in the receiving jurisdiction. Id. at paras 40-41.

${ }^{22}$ For discussion of the current leniency system in the EU, including its deficits, see Maria Jaspers, 'Designing a European Solution for a "One-Stop Leniency Shop"', 27(12) European Competition Law Review 685 (2006).
} 
allow now for oral applications. ${ }^{23}$ Moreover, both the US and European competition authorities have a tradition of strongly protecting leniency related documents. ${ }^{24}$ In the EU context discoverability of leniency applications was recently tested in Pfleiderer $^{25}$ and the Court of Justice did not preclude it. ${ }^{26}$ It ruled that it is up to the national courts to decide on a case by case basis under which conditions to grant or refuse access under national law, by balancing the interests protected by EU law (effectiveness of leniency programmes being one of them $\left.{ }^{27}\right){ }^{28}$ While threat of discoverability of leniency documents is a challenge, it is not specific to inter-agency cooperation. The same issue arises when a disclosure order is addressed not to the competition authority, but to the leniency applicant itself in private enforcement actions at the national level. ${ }^{29}$

It is also argued that inter-agency exchange of evidence may have negative impact on due process rights/ procedural fairness, especially in those jurisdictions in which anticompetitive conduct is subject to criminal sanctions. The high level of protection of

\footnotetext{
${ }^{23}$ Compare Sweeney, above note 7 , at 304.

${ }^{24}$ From the EU and US perspective see Caroline Cauffman, The Interaction of Leniency Programmes and Actions for Damages', 7(2) Competition Law Review 181 (2011); Samuel R. Miller, et al., 'US Discovery of European Union and US Leniency Applications and other Confidential Investigatory Materials', March 2010(1) CPI Antitrust Chronicle (2010). For more on the issue of disclosure of leniency materials from broader international perspective see Marc Hansen, et al., 'New Fault Lines in International Cartel Enforcement and Administration of Leniency Programs- Disclosure of Immunity Applicant Statements' (ABA International Cartel Workshop- Vancouver 2012), 〈http://www.lw.com/upload/pubContent/_pdf/pub4546_1.pdf>.

${ }^{25}$ Case C-360/09, Pfleiderer AG v. Bundeskartellamt [2011] ECR ECR I-05161. In this case Pfleiderer, a German company- a purchaser of decor paper, wanted to bring a follow-on action after the Bundeskartellamt, the German NCA, fined a number of companies and individuals active on the decor paper manufacturing market for their violations of the EU competition law. Pfleiderer sought access to the case file and was dissatisfied with the limited access it was granted, looking for full access also to the leniency applications voluntarily submitted to the NCA under the German leniency scheme. The German district court hearing the case asked the ECJ for its guidance on where granting such access is in line with the EU law. Interestingly, AG Mazák in its Opinion distinguished between leniency applications and all other pre-existing documents submitted by the leniency applicant, considering that access to the former should not be in principle granted, whereas access to the latter should be allowed. Case C360/09, Opinion of Mr Advocate General Mazák in case Pfleiderer AG v. Bundeskartellamt [2011] ECR I-05161, paras 44-47. The District Court delivered its judgment in light of the ECJ's ruling. Having balanced the different interests it granted Pfleiderer access to a non-confidential version of the case file, with the exception of the statements and evidence provided by the leniency applicants and the internal records of the Bundeskartellamt. District Court of Bonn, Decision of 18 January 2012, Case 51 Gs 53/09 (AG Bonn 2012). For discussion of possible practical consequences see Caroline Cauffman, 'Access to Leniency Related Documents after Pfleiderer' (Maastricht Faculty of Law Working Paper No. 3, 2012), <http://ssrn.com/paper=2004958>. See further Bruce Wardhaugh, 'Cartel Leniency and Effective Compensation in Europe: The Aftermath of Pfleiderer', 19(3) Web Journal of Current Legal Issues (2013), <http://webjcli.org/article/view/251>.

${ }^{26}$ Pfleiderer, above note 25 , at para 32.

${ }^{27}$ It is noteworthy that for the first time the ECJ acknowledged that the functioning of leniency programmes is an interest protected by EU law. Id. at paras 25-27. Note that confidentiality is also a right protected under the EU Law. See below notes 47-59 and accompanying text.

${ }^{28} I$. at paras $31-32$.

${ }^{29}$ Cauffman, above note $25,12-13$.
} 
due process rights applicable in criminal investigations may be undermined if materials collected for the purposes of civil investigation or administrative proceedings are passed on and then used in a criminal investigation. ${ }^{30}$ This is a valid concern. The European Court of Human Rights has established that under Article 6 of the European Convention of Human Rights evidence obtained under compulsion in a non-judicial investigation may not be used to incriminate the accused in criminal proceedings. ${ }^{31}$ In the EU context this issue is addressed under the Regulation 1/2003. The Commission and the NCAs can exchange confidential information for the purpose of applying the EU competition provisions, but such information can only be used as evidence to impose sanctions on natural persons where the law of the transmitting authority foresees sanctions of a similar kind in relation to an infringement of Article [101] or Article [102] of the Treaty' or when 'the information has been collected in a way which respects the same level of protection of the rights of defence of natural persons as provided for under the national rules of the receiving authority. ${ }^{, 32}$ Similar safeguards could be introduced in inter-agency arrangements beyond the EU.

There is also a mercantilistic argument against inter-agency evidence cooperation: the sharing of information by antitrust authorities is likely to lead to domestic companies being sanctioned in foreign jurisdictions, even when no harm has been caused by the investigated firms on their home markets. ${ }^{33}$ This would negatively affect national welfare. Even in a case of an international cartel challenged in a number of jurisdictions, from the cartel's host state perspective the higher the foreign fines are, the higher is the outflow of wealth from the country and the more affected will be the fined

\footnotetext{
${ }^{30}$ Chowdhury, above note $13,19$.

${ }^{31}$ Saunders v. United Kingdom 23 EHRR 313, para 74 (ECtHR 1997). For discussion see Renato Nazzini, 'Some Reflections on the Dynamics of the Due Process Discourse in EC Competition Law', 2(1) Competition Law Review 6 (2005), at 17-19.

${ }^{32}$ Art. 12(3) of Council Regulation (EC) No 1/2003 of 16 December 2002 on the Implementation of the Rules on Competition laid down in Articles 81 and 82 of the Treaty OJ L 1, 1-25 (2003).

${ }^{33}$ Chowdhury, above note $13,19-20$.
} 
firm's competitive position (versus its foreign competitors). The tolerance of export cartels (agreements between competitors affecting only foreign markets) in virtually all jurisdictions is the best example that such mercantilistic considerations are present. ${ }^{34}$ Yet this is a short-sighted approach. Firstly, it is a double-edged sword since a state that is unwilling to share information should expect similar, reciprocal reaction of other states. Secondly, such a mercantilistic approach, if followed persistently, may have negative spillover effects beyond competition law, potentially affecting the state's foreign relations. Furthermore, such thinking presupposes that private capital (the challenged firm) will be in some way 'faithful' to the host state. This need not to be so and often it is not the case. Multinational firms often slice and relocate production processes internationally, use transfer-pricing and other tools to optimize (that is, minimize) their tax obligations in any given state.

Finally and in more general terms, the issue of close inter-agency cooperation raises concerns about sovereignty. Sharing of evidence facilitates extraterritorial enforcement of foreign antitrust laws, which may be considered - either generally or in a particular case-as encroaching on sovereignty of the affected state. ${ }^{35}$ Such fundamental disagreements are nowadays rare, yet the recent enactment of blocking legislation in Russia in response to European Commission's investigation of Gazprom practises in the EU shows that they cannot be ruled out. ${ }^{36}$

\footnotetext{
${ }^{34}$ See further Marek Martyniszyn, 'Export Cartels: Is it Legal to Target Your Neighbour? Analysis in Light of Recent Case Law', 15(1) Journal of International Economic Law 181 (2012); D. Daniel Sokol, 'What do We Really Know About Export Cartels and What is the Appropriate Solution?', 4(4) Journal of Competition Law and Economics 967 (2008).

${ }^{35}$ In similar vein Judge Wood, when commenting on the benefits of inter-agency cooperation, notes 'I would not expect one country to assist another in pursuing a case that the first country regarded as an impermissible effort at extraterritorial regulation'. Compare Diane P. Wood, 'Is Cooperation Possible', 34 New England Law Review 103 (1999), at 108-09.

${ }^{36}$ For discussion of blocking legislation see Marek Martyniszyn, 'Legislation Blocking Antitrust Investigations and the September 2012 Russian Executive Order', 37(1) World Competition 103 (2014).
} 
At the same time none of the above concerns regarding inter-agency confidential information sharing rules out cooperation. Many of them can be addressed by suitable safeguards or procedural arrangements. For example, the need for protection of important national interests may be addressed by a provision allowing for a refusal of cooperation in cases of particularly high political importance, while allowing for cooperation in all other cases. The appropriate caveats concerning protection of individual procedural justice can be explicitly provided for in cooperation agreements.

Some arguments, like the one concerning business secrets, while intuitively appealing, are unsubstantiated. The object of exchange between agencies in this context is not 'the secret formula for Coca-Cola', a trade secret, but the proof of antitrust violation. ${ }^{37}$ Moreover, while under merger review the authorities are likely to analyse business sensitive information such as strategies or future plans (prospective focus of review), historic information (retrospective data) is the focus of cartel investigations. ${ }^{38}$ Investigators are looking for, for example, evidence of meetings or communications between firms, regarding pricing, markets, or sales policies. In practice such evidence is often found in handwritten notes, calendars entries, phone logs, and does not address important prospective business strategy. ${ }^{39}$

As Matsushita rightly points out, if exchange of evidence could have been achieved, for example, in tax law (for instance, under the US-Japan Tax Treaty), it should be possible also in competition law. ${ }^{40}$ This effectively debunks what Hammond calls one of the myths and misconceptions concerning inter-agency information sharing. He argues that there is no reason why antitrust violations should be treated differently from

\footnotetext{
${ }^{37}$ Hammond, above note $15,4-5$.

${ }^{38} \mathrm{Id}$. at 5.

${ }^{39}$ Id.

${ }^{40}$ Mitsuo Matsushita, 'International Cooperation in the Enforcement of Competition Policy', 1 Washington University Global Studies Law Review 463 (2002), at 473.
} 
deceit or fraud. ${ }^{41}$ The issue of competition law criminalization aside, ${ }^{42}$ it is difficult not to agree with Hammond's argument.

Nevertheless, the lack of a widespread mechanism allowing for close cooperation between agencies, as Judge Wood notes, ${ }^{43}$ means that: (1) states value 'sovereign prerogatives above the added benefits for competition law enforcement', and (2) companies are satisfied with the reality in which the antitrust authorities 'must operate with one hand tied behind their back'. There should be no doubt that companies suffer harm from anticompetitive conduct. While many may try to pass on the harm to their customers (and ultimately consumers) by raising prices, this will not always happen, especially on very competitive markets. Therefore there is no reason why legally compliant businesses should not favour information sharing arrangements between agencies. $^{44}$

\section{PROTECTION OF CONFIDENTIALITY: THE EU AND US PERSPECTIVES}

At the international level there is no common definition of confidential information. ${ }^{45}$ Definitions and standards of protection differ between jurisdictions. In the EU confidentiality is protected by provisions of both primary and secondary EU law. Article 339 TFEU prohibits disclosure of 'information of the kind covered by the

\footnotetext{
${ }^{41}$ Scott D. Hammond, 'Beating Cartels at Their Own Game- Sharing Information in the Fight' (Symposium on Competition Policy by the Competition Policy Research Center, Fair Trade Commission of Japan, Tokyo 2003), 6-7, $\langle$ http://www.justice.gov/atr/public/speeches/201614.pdf $>$.

${ }^{42}$ For normative discussion and analysis see Bruce Wardhaugh, 'A Normative Approach to the Criminalisation of Cartel Activity', 32(3) Legal Studies 369 (2012).

${ }^{43}$ Wood, above note 35 , at 110 .

${ }^{44}$ In this vein also Hammond, above note 15, 11-12. From a compliance perspective, it is also a matter of how antitrust violations and the enforcement efforts are perceived by the business community and the general public. If in a particular regime anticompetitive conduct is thought of as some sort of 'bad business practice' and not as socially and morally unacceptable conduct, enforcement efforts may be seen as unfair or illegitimate. See, for example, Christine Parker, 'The "Compliance" Trap: The Moral Message in Responsive Regulatory Enforcement', 40(3) Law \& Society Review 591 (2006).

${ }^{45}$ For a brief overview of the criteria commonly used to define confidential information see International Enforcement Co-operation: Secretariat Report on the OECD/ICN Survey on International Enforcement Co-operation, above note 6 , at 121-122.
} 
obligation of professional secrecy, in particular information about undertakings, their business relations or their cost components. ${ }^{46}$

This general rule is implemented in the area of competition law by the Council Regulation 1/2003, ${ }^{47}$ which gives the European Commission investigative powers in the field of competition law. The unique and one-of-its kind intra-EU arrangement aside, ${ }^{48}$ the information collected by the Commission may be used 'only for the purpose for which it was acquired'. ${ }^{49}$ The Commission and the NCAs, their officials and other persons working under their supervision are under an obligation not to disclose 'information acquired or exchanged by them pursuant to this Regulation and of the kind covered by the obligation of professional secrecy. ${ }^{50}$ For example, on this basis in 2004 the Commission rejected the Turkish competition authority's request to access evidence collected by the Commission in its investigation on the electrical equipment market. ${ }^{51}$

Furthermore, under the Commission's Staff Regulation ${ }^{52}$ any unauthorized disclosure of information is prohibited, unless that information has already been made public or is accessible to the public. ${ }^{53}$ The officials are bound by this prohibition also after leaving the service for the Commission. ${ }^{54}$ In case of damage caused by a breach of confidentiality in violation of the aforementioned provisions by the Commission's staff

\footnotetext{
${ }^{46}$ See in greater details Christopher Kerse and Nicholas Khan, EC Antitrust Procedure (London: Sweet \& Maxwell, 2005), paras 2-069-2-073.

${ }^{47}$ Council Regulation (EC) No 1/2003, above note 32. So as to facilitate protection of confidential information in competition cases, the European Commission's DG Competition published guidance on confidentiality of submissions. It summarized what sort of information may and what may not constitute business secrets and other confidential information under EU law. European Commission, 'Annex on Business Secrets and Other Confidential Information' (2012), 〈http://ec.europa.eu/competition/antitrust/business_secrets_en.pdf>. This guidance was followed by a publication of an even more practical note, including examples of how to mark confidential information in documents and how to prepare their non-confidential versions. See European Commission, 'DG Competition Informal Guidance Paper on Confidentiality Claims' (2012), <http://ec.europa.eu/competition/antitrust/guidance_en.pdf >.

${ }^{48}$ See below notes 70-72 and accompanying text.

${ }^{49}$ Art. 28(1) of the Regulation, above note 32.

${ }^{50}$ Id. at Art. 28(2).

${ }^{51}$ Maher M. Dabbah, International and Comparative Competition Law (Cambridge: CUP, 2010) 519-20.

${ }^{52}$ Council Regulation (EC, EURATOM) No 723/2004 of 22 March 2004 amending the Staff Regulations of officials of the European Communities and the Conditions of Employment of other servants of the European Communities, OJ L 124, 1-118 (2004).

${ }^{53}$ Id. at Art. 17(1).
${ }^{54}$ Id. at Art. $17(2)$.
} 
in the performance of their duties, an undertaking could bring an action for damages against the Union under Article 340(2) TFEU. ${ }^{55}$ Extralegally, any breach of confidentiality by the Commission's or NCA's staff would cause considerable reputational damage, both to the institution and the individual concerned.

Adams $v$ Commission is probably the most infamous case on breach of EU rules on confidentiality in competition law enforcement. ${ }^{56}$ In the underlying proceedings, in the mid-1970s, the Commission made available to the investigated Swiss firm (later found in violation of EU rules ${ }^{57}$ ) copies of the documents provided by Adams - the informant — without his consent. ${ }^{58}$ This allowed the firm to identify Adams. On return to Switzerland he was arrested, and later convicted of industrial espionage. Subsequently, the ECJ found the Commission in breach of its obligations regarding confidentiality. Adams was awarded damages. ${ }^{59}$ This case shows that even most striking breaches of confidentiality may occur in the well-developed competition regimes.

Similarly high standard of confidentiality is provided for under US legislation. Under the Antitrust Civil Process Act (ACPA), laying down the rules governing civil investigations, no documents or transcripts produced pursuant to a compulsory process can be made publicly available without the consent of the party that provided such materials. ${ }^{60}$ They may be used, when necessary, before any court, grand jury or federal agencies. They may be also disclosed to either body of the Congress or to any

\footnotetext{
${ }^{55}$ If the conduct giving rise to damage was performed outside the course of the official duties, the EU will not be liable. The undertaking should bring then an action for damages against the individual involved before a competent (ratione loci) national court and the issue of liability would be addressed under the law of the forum. Alina Kaczorowska, European Union Law, 2nd ed. (London: Routledge-Cavendish, 2010) 466-83; Trevor C. Hartley, The Foundations of European Union Law, 7th ed. (Oxford: OUP, 2010) 451-64.

${ }^{56}$ Case 145/83 Stanley Adams v Commission, [1985] ECR 3539.

${ }^{57}$ European Commission, 76/642/EEC, Decision of 9 June 1976 Relating to a Proceeding under Article 86 of the Treaty Establishing the European Economic Community, IV/29.020- Vitamins, OJ L223, 27-38 (1976). The decision was confirmed in all essential respects. See Case 85/76, Hoffmann-La Roche v. Commission, [1979] ECR 461.

${ }^{58}$ Id. at $3589-3590$.

${ }^{59}$ Adams also complained that the Commission failed to warn him about the threat of criminal investigation upon his return to Switzerland. This was another factor which gave rise to Commission's liability. Adam's dramatic story, involving his wife suicide, served as a basis for a movie 'A Song for Europe' (1985), directed by John Goldschmidt. For details see <http://www.imdb.com/title/tt0088964/>.

${ }^{60} 15$ U.S.C. Section 1313 (c)(3).
} 
authorised committee or subcommittee thereof. Also the Federal Rule of Criminal Procedure 6(e), governing grand jury investigations (criminal cases), prevents the US antitrust authorities from sharing information which they have obtained in the course of their proceedings. ${ }^{61}$ Similar provisions can be found in the Clayton Act $^{62}$ and the Federal Trade Commission Act. ${ }^{63}$

Even the Agreements between the United States and the European Commission, ${ }^{64}$ two closely cooperating antitrust regimes, while explicitly recognizing common interest in sharing information, ${ }^{65}$ did not alter the existing laws governing confidentiality. ${ }^{66}$ Moreover, the Cooperation Agreement underlined that neither Party was required to provide the other Party any information which disclosure was prohibited under the law of the requested Party. ${ }^{67}$ The net effect of the Agreement in terms of information exchange is that the agencies can share confidential information only if the source of the information explicitly grants a waiver. ${ }^{68}$ However, there are other agreements and even unilateral arrangements, which provide for sharing of confidential information between agencies. These are discussed in the following part.

\footnotetext{
${ }^{61}$ Rule 6(e)(3) lists expectations allowing for disclosure of grand jury materials, and although there is little precedent in this regard it seems that none of exceptions would apply in case of a request from a foreign competition agency. American Bar Association, Section of Antitrust Law, International Antitrust Cooperation Handbook (ABA, Section of Antitrust Law, 2004) 26-28.

62 'Any information or documentary material filed with the Assistant Attorney General or the Federal Trade Commission pursuant to this section shall be exempt from disclosure ..., and no such information or documentary material may be made public, except as may be relevant to any administrative or judicial action or proceeding.' 15 U.S.C. Section 18(a)(h), as amended by the Hart Scott-Rodino Act of 1976.

63 .... the Commission shall not have any authority to make public any trade secret or any commercial or financial information which is obtained from any person and which is privileged or confidential, except that the Commission may disclose such information to officers and employees of appropriate Federal law enforcement agencies or to any officer or employee of any State law enforcement agency upon the prior certification of an officer of any such Federal or State law enforcement agency that such information will be maintained in confidence and will be used only for official law enforcement purposes.' 15 U.S.C. Section 46(f). See also 15 U.S.C. Section 57-2(b).

${ }^{64}$ Agreement between the Government of the United States of America and the Commission of the European Community Regarding the Application of Their Competition Laws, OJ L 95, 47 (1995), Agreement between the European Communities and the Government of the United States of America on the Application of Positive Comity Principles in the Enforcement of Their Competition Laws, OJ L 173, 28 (1998).

${ }^{65}$ Art. III of the 1995 Cooperation Agreement, above note 64.

${ }^{66} \mathrm{Id}$. at Art. IX. The Positive Comity Agreement did not introduce any changes in this regard.

${ }^{67}$ Such a disclosure is also not required if it would be incompatible with important interests of the Party possessing the information. Compare Art. VIII(1) of the Cooperation Agreement, above note 64.

${ }^{68}$ Chowdhury, above note $13,9$.
} 


\section{EXISTING LEGAL FRAMEWORKS ALLOWING FOR EXCHANGE OR SHARING OF EVIDENCE}

Generally sharing of confidential information between agencies transnationally is possible only when special rules to that end have been adopted. The intra-EU framework in that regard is the most far-reaching one. It allows NCAs to exchange evidence, and also to carry out inspections and other fact-finding measures for other NCAs. Apart from this unique intra-EU arrangement, there are few legal instruments (bilateral or plurilateral), allowing for confidential information sharing. Besides these special tools legislation of a few states (most notably of Australia, Canada, and UK) permits, under certain circumstances, their competition authorities to share confidential information unilaterally (without any specific agreement in that regard). ${ }^{69}$ In this part such international and domestic solutions will be identified and evaluated from the perspective of their practical relevance in transnational competition law enforcement. The attention is first turned towards the special intra-EU framework.

The case of the EU is unique. While the European Commission remains the main enforcer, EU competition law is also enforced at the national level. In this intra-EU context, NCAs collaborate very closely. Under the Regulation 1/2003 they can exchange evidence, including confidential information, for the purpose of applying EU competition provisions. ${ }^{70}$ Moreover, NCAs are empowered to carry out inspections and other fact-finding measures under their national laws in the enforcement of EU competition laws, on behalf and for the account of NCAs from other Member States. ${ }^{71}$ Recognising differences in competition law between Member States, special safeguards were incorporated to prevent any negative impact on due process rights. ${ }^{72}$ While these

\footnotetext{
${ }^{69}$ Compare OECD, above note 9 , at 40 .

${ }^{70}$ Council Regulation (EC) No 1/2003, above note 32, Art. 12.

${ }^{71}$ Art. 22(1) of the Regulation.

${ }^{72}$ See above text accompanying notes 30-32.
} 
are very close forms of cooperation in enforcement, any lessons drawn from intra-EU experience must acknowledge that this framework was developed against the backdrop of years of European integration and trust-building.

It should be added that in May 2013 the European Union signed a new Cooperation Agreement with the Swiss Confederation regarding competition law enforcement. ${ }^{73}$ After coming into force ${ }^{74}$ the Agreement will allow competition authorities to exchange evidence, albeit only in parallel proceedings. ${ }^{75}$ It also incorporates a number of safeguards. For example, neither Party is required to offer such assistance if it was to be incompatible with its important interests or unduly burdensome. ${ }^{76}$ Information obtained under leniency programmes or settlement procedures cannot be discussed or exchanged without the express consent of the source. ${ }^{77}$ Furthermore, discussed or exchanged information cannot be used to impose sanctions on natural persons. ${ }^{78}$ Overall, the Agreement is a significant step forward in EU-Swiss enforcement cooperation in competition law.

Internationally, the first legal instruments which enabled closer cooperation between antitrust agencies were Mutual Legal Assistance Treaties in Criminal Matters (MLATs). MLATs are bilateral or, occasionally, plurilateral agreements, popularized by the US, ${ }^{79}$ facilitating gathering and access to foreign-based evidence in criminal cases. ${ }^{80}$ Given

\footnotetext{
73 'Agreement between the European Union and the Swiss Confederation Concerning Cooperation on the Application of Their Competition Laws', (2013),

<http://ec.europa.eu/competition/international/bilateral/agreement_eu_ch_en.pdf >. See discussed in Patrik Ducrey, 'The Agreement between Switzerland and the EU Concerning Cooperation in the Application of their Competition Laws', 4(5) Journal of European Competition Law \& Practice 437 (2013).

${ }^{74}$ The Agreement is not yet in force. It awaits consent of the European Parliament. For current statute of the Agreement see < http://ec.europa.eu/competition/international/bilateral/>.

${ }^{75}$ Art. 7(4) of the Agreement, above note 73.

${ }^{76}$ Id. Art. 7(5).

${ }^{77}$ Id. Art. 7(6).

${ }^{78}$ Id. Art. 8(4).

${ }^{79}$ US signed its first agreement of this kind in 1973. See Mutual Assistance in Criminal Matters between Switzerland and the United States, signed 25 May 1973, entered into force 23 January 1977, 27 UST 2019, TIAS 8302. Under Art.2(1)(c)(4) this Agreement is inapplicable to antitrust.

${ }^{80}$ A notable exception is the US-German MLAT which provides for US assistance with regard to 'regulatory offences under German antitrust law'. Treaty between the United States of America and the Federal Republic of
} 
that relatively few jurisdictions treat infringements of competition laws as criminal offences, ${ }^{81}$ and that MLATs usually require that the conduct at stake is treated as a crime in both jurisdictions before the cooperation can take place (the dual criminality requirement), the impact of MLATs is limited. For example, the MLAT between the US and $\mathrm{EU}^{82}$ is inapplicable in antitrust as the European Commission itself has no inherent criminal law powers and it is constrained in competition law enforcement by the rules governing both exchange of information and general rules on confidentiality. ${ }^{83}$ The MLATs between US and Canada, and US and UK allow for cooperation in antitrust cases. ${ }^{84}$

Germany on Mutual Legal Assistance in Criminal Matters, Treaty Doc. 108-27, 108th Cong. 2d Sess.; Exec. Rept. 109-14, 109th Cong. 2d Sess. (2003). Note that in 2006 the US and Germany signed a Supplementary Treaty (Treaty Doc. 109-13, 109th Cong. 2d Sess.). Both Treaties entered into force in October 2009. Rachel Brandenburger, the Special Advisor, International to the Assistant Attorney General for the US DoJ Antitrust Division (since 2010), considered the stipulations of the US-German MLAT 'unique', being 'a product of long-term US-German cooperation'. Rachel Brandenburger, 'The Many Facets of International Cooperation at the Antitrust Division', 5, n 8 (Remarks as Prepared for International Bar Association Midyear Conference, Madrid 2012), 〈http://www.justice.gov/atr/public/speeches/284239.pdf>.

${ }^{81}$ See Mark Furse, 'Issues Relating to the Enforcement and Application of Criminal Laws in Respect of Competition' in Philip Marsden (ed), Handbook of Research in Trans-Atlantic Antitrust (Cheltenham: Edward Elgar, 2006). Compare Katalin J. Cseres, et al. (eds), Criminalization of Competition Law Enforcement: Economic and Legal Implications for the EU Member States (Edward Elgar, 2006). In the aftermath of criminalization of competition law the pre-existing extradition treaties become a potentially powerful tool in antitrust enforcement. This issue was at the heart of the Norris case. In 2002, in connection with a US antitrust investigation in a carbon components manufacturing cartel, two UK-based subsidiaries of one of the US companies involved pleaded guilty to counts of tampering with witnesses and documents destruction. The US grand jury indicted Ian Norris, the former CEO of one of the subsidiaries, on obstruction of justice and price-fixing counts. The US DoJ sought to extradite Norris to the US under the US-UK Extradition Treaty. This attempted initially failed. In 2008 the House of Lords held that price fixing was not considered a crime in the UK at the time in question (that is before the introduction of the cartel offence in the UK in 2003), and the US-UK Extradition Treaty required double criminality. Yet, the Lords had left the question open whether Norris could be extradited on the ground of the obstruction of justice. The lower courts allowed for extradition on this basis (later affirmed by the UK Supreme Court). In March 2010, after the ECtHR rejected Norris' appeal on human rights grounds, the UK extradited Norris to stand trial in the US. For the US DoJ Antitrust Division it was the first time to succeed in seeking extradition of a foreign national. In 2010 Norris was found guilty of conspiring to obstruct justice. He was sentenced to serve eighteen months in prison. The Norris case brought the extradition issue into the limelight for the antitrust audience, although its impact is rather limited. Most extradition treaties contain the double criminality requirement. Some older treaties list extraditable offences, but the cartel offence is not to be found on such lists. Moreover, some jurisdictions do not extradite their own citizens (for example Germany), or retain discretion in this regard (for example Australia). In effect, it seems that extradition on competition law grounds can effectively take place only among the US, the UK, Ireland, and Canada. See further James A. Wilson, 'Extradition: The New Sword or the Mouse that Roared?', 4 Antitrust Source (2011), 〈http://www.americanbar.org/content/dam/aba/publishing/antitrust_source/apr11-wilson_4-20f.authcheckdam.pdf >. For the analysis of Norris and its implication for the UK competition law enforcement see Peter Whelan, 'Resisting the Long Arm of Criminal Antitrust Laws: Norris v The United States', 72(2) Modern Law Review 272 (2009).

${ }^{82}$ Agreement on Mutual Legal Assistance between the European Union and the United States of America, OJ L 181, 34 (2003). See further See Julian M. Joshua, 'Mutual Legal Assistance. Brave New World: A North Atlantic Triple Entente against cartels?', March 2004 Competition Law Insight 16 (2004), at 17.

${ }^{83}$ In this context see above notes $46-54$ and accompanying text.

${ }^{84}$ The US-UK MLAT was originally amended by an exchange of diplomatic notes and made inapplicable to antitrust investigations. This exception was later abandoned under the Agreement concerning the Application of the Treat on Mutual Legal Assistance in Criminal Matters (effected by an exchange of notes dated 30 April and 1 May 
More recent MLATs tend not to require double criminality ${ }^{85}$ or require it only for certain types of assistance. ${ }^{86}$ Therefore the US could, in principle, request assistance under such MLATs in antitrust cases, although it may be that in this area of law assistance would be either discretionary under particular MLATs, or would be simply rejected as prejudicial to the receiving country's sovereignty or its essential interests. ${ }^{87}$ In any case, such assistance would be largely one-sided as relatively few jurisdictions criminalized their competition laws and therefore they are unable to rely on MLATs to seek help of US agencies in their investigations. ${ }^{88}$

It seems that the first MLAT which specifically covered antitrust crimes was signed in 1985 between the US and Canada. ${ }^{89}$ This Treaty obliges both parties to assist each other in 'investigation, prosecution and suppression of offences' .90 The antitrust criminal cases fall under the scope of the Treaty under the notion of 'consumer protection'. ${ }^{91}$ The commitment to cooperation is expansive. It includes cooperation irrespective of whether the conduct at stake constitutes an offence or may be prosecuted in the Requested State (no double criminality requirement). ${ }^{92}$ This is somewhat limited given that the assistance may be denied if the request under the Treaty is considered

2001). As the UK later introduced criminal sanctions for competition law violations (under the Enterprise Act 2002), antitrust agencies from both jurisdictions can avail of the MLAT in criminal antitrust cases. Compare International Antitrust Cooperation Handbook, above note 61, at 276-77; Julian M. Joshua, et al., 'Extradition and Mutual Legal Assistance Treaties: Cartel Enforcement's Global Reach', 75 Antitrust Law Journal 353 (2008), at 389.

${ }^{85}$ For example, the MLAT between the US and South Korea provides, in Art. 3(2), that the assistance with regard to certain categories of crimes shall be provided irrespective of whether the conduct at stake constitutes an offence in the Requested State. Annex to the Treaty lists these categories, among them, under para 20: '(o)ffenses against the laws relating to prohibition of private monopolies or unfair business translations or practices', which cover antitrust offences. Treaty between the United States of America and the Republic of Korea on Mutual Legal Assistance in Criminal Matters, Treaty Doc. 104-1 (1995).

${ }^{86}$ Bruce Zagaris, 'United States Treaties on Mutual Assistance in Criminal Matters' in M. Cherif Bassiouni (ed), International Criminal Law: Multilateral and Bilateral Enforcement Mechanisms, 3rd ed. (Martinus Nijhoff, 2008) $388-89$.

${ }^{87}$ Julian M. Joshua, 'Mutual Legal Assistance. Brave New World: A North Atlantic Triple Entente against cartels?', March 2004 Competition Law Insight 16 (2004), at 17-18.

${ }^{88}$ But for German competition authority which can, under the special provisions of the US-German MLAT, request help from US counterparts in its administrative proceedings. See above note 80 .

${ }^{89}$ Canada- United States: Treaty on Mutual Legal Assistance in Criminal Matters, 24 I.L.M. 1092 (1985). Compare Spencer Weber Waller, 'The Internationalization of Antitrust Enforcement', 77 Boston University Law Review 343 (1997), at 370.

${ }^{90}$ Art. 2(1) of the Treaty, above note 89.

${ }^{91}$ Annex to the Treaty defines the scope of its applicability by clarifying that it covers offences under US laws in such categories as securities, wildlife, environmental and consumer protection.

${ }_{92}$ Art. 2(3) of the Treaty, above note 89. 
contrary to the Requested State's public interest, ${ }^{93}$ which is a standard provision in MLATs. Since its introduction the US-Canada MLAT has been actively utilized in criminal antitrust cases. ${ }^{94}$

From antitrust enforcement perspective despite their advantages MLATs suffer from various limitations. As MLATs apply to criminal investigations they are generally of no use in administrative proceedings or civil cases. Moreover, provisions of MLATs do not necessarily override domestic rules governing confidentiality. Not all competition authorities may be able to share information obtained through their own enforcement measures. ${ }^{95}$ This drawback applies also to US agencies, which due to the stringency of US rules on confidentiality in criminal matters (which are not overridden by provisions of MLATs) are unable to share grand jury materials. ${ }^{96}$

So as to address some of the limitations of MLATs in antitrust, in 1994 the US Congress enacted the International Antitrust Enforcement Assistance Act (IAEAA). ${ }^{97}$ The Act was intended to improve access to foreign-based evidence in civil antitrust cases, including information collected by the agencies through their own investigatory powers. ${ }^{98}$ The IAEAA created a framework under which the Federal Trade Commission (FTC) and DoJ are empowered to negotiate antitrust mutual assistance agreements

\footnotetext{
${ }^{93} I d$. at Art. 5(1)(b).

${ }^{94}$ Waller, above note 89 , at 368 .

${ }^{95}$ For example, Section 29 of the Canadian Competition Act provides for rigid confidentiality protection. Competition Act, RSC 1985, c C-34, <http://canlii.ca/t/krnt>. The Canadian legislation implementing the US-Canada MLAT, in its Section 3(1), provides that the provisions of the Act override provisions of other statutes but for those which prohibit the disclosure of information or prohibit disclosure of information except under certain conditions. Mutual Legal Assistance in Criminal Matters Act, RSC 1985, c 30 (4th Supp), <http://canlii.ca/t/hz0l>. In practice it means that Canadian authorities cannot share with US counterparts information obtained in their own investigations. This has no impact on passing on information obtained pursuant to requests under the MLAT as that is a separate procedure not falling under the confidentiality requirement of the Competition Act.

${ }^{96}$ See above note 61 and accompanying text.

${ }^{97} 15$ U.S.C. Sections 6201-6212.

${ }^{98}$ The IAEAA defines antitrust evidence broadly as encompassing 'information, testimony, statements, documents, or other things that are obtained in anticipation of, or during the course of, an investigation or proceeding under any of the Federal antitrust laws or any of the foreign antitrust laws.' 15 U.S.C. Section 6211(1).
} 
(AMAAs) allowing for exchange of confidential information ${ }^{99}$ on a mutual basis (a condition sine qua non) with foreign counterparts, while preserving its confidentiality. ${ }^{100}$ Exchange of information under AMAAs applies to criminal, civil and merger matters. The assistance may be provided regardless of whether the conduct in question violates US antitrust laws. ${ }^{101}$ Apart from sharing information, the US agencies may actively use their powers to gather evidence for the use by foreign counterparts. ${ }^{102}$ Moreover, on an application of the Attorney General a US district court may order a person to, for example, give testimony or a statement in a particular form, including under oath. ${ }^{103}$ These provisions explicitly allow for taking evidence in line with foreign procedures (so long as they are in accordance with the Federal Rules of Civil Procedure), ${ }^{104}$ addressing admissibility of so-obtained evidence in foreign proceedings.

The IAEAA makes an exception to US rules governing confidentiality and enables the US agencies to share information obtained through civil investigative demands with signatories of AMAAs. ${ }^{105}$ Moreover, provisions of the IAEAA expand the list of exceptions allowing for disclosure of grand jury materials, regardless of whether the foreign competition laws are civil, criminal, or administrative in nature, so long as the foreign authority shows 'a particularized need' for such disclosure. ${ }^{106}$

\footnotetext{
${ }^{99}$ A reservation was made with regard to information received by the antitrust authorities under pre-merger notification system. 15 U.S.C. Section 6204(1). This provision was called for by the US business community which argued that any inappropriate disclosure of merger-related materials, as particularly sensitive and prospective in nature, would cause a serious damage to the competitiveness of US firms. Laurie N. Freeman, 'US-Canadian Information Sharing and the International Antitrust Enforcement Assistance Act of 1994', 84 Georgetown Law Journal 339 (1995), at 357-58.

${ }^{100} 15$ U.S.C. Section 6211(2)(b).

10115 U.S.C. Section 6202(c).

102 15 U.S.C. Section 6202(b).

10315 U.S.C. Section 6203.

104 15 U.S.C. Section 6203(b)(2)(B).

10515 U.S.C. Section 6205.

10615 U.S.C Section 6204(2). Compare above note 61. For more detailed discussion of the changes made by the IAEAA with regard to disclosure of grand jury materials and the understanding of the notion of 'a particularized need', not defined in the IAEAA, see International Antitrust Cooperation Handbook, above note 61, at 50-51.
} 
The first and only agreement adopted under the IAEAA ${ }^{107}$ was entered into between the US and Australia in $1999 .{ }^{108}$ It follows the spirit of the IAEAA and commits both Parties to offer each other assistance and cooperate in providing and obtaining antitrust evidence. ${ }^{109}$ The said assistance includes disclosure and exchange of evidence, taking testimonies, obtaining documentary evidence, as well as executing searches and seizures. ${ }^{110}$ The US-Australia Agreement has been availed of at least once by Australia in its investigation of the Vitamins cartel. ${ }^{111}$ It is unclear if that was the same or another case but the Australian authorities report gaining access, under the Agreement, to US grand jury materials, which proved very useful in the Australian investigation. ${ }^{112}$

While the IAEAA created a new framework for cooperation agreements, it seems that other states would benefit little from entering into AMAAs with the US. Firstly, apart from the EU there was, at least in past, little appetite for extraterritorial enforcement of competition laws. Entering into an AMAA with the US (whose laws provide for far-reaching extraterritorial jurisdiction and whose antitrust agencies have the necessary capacity to avail of it) could be seen as simply allowing the US agencies to reach for foreign firms with little benefit offered in return, and at considerable sunk costs (involved in the negotiation of the agreement). Secondly, foreign parties to a large extent already have access to US-based evidence thanks to means of international

\footnotetext{
${ }^{107}$ Federal Trade Commission, 'First International Antitrust Assistance Agreement Under New Law Announced By FTC And DOJ' (17 April 1997), <http://www.ftc.gov/opa/1997/04/iaeaa.shtm>. Waller notes that after the IAEAA entered into force the US antitrust agencies started talks with the Canadian government with an aim to conclude an AMAA. This was the logical step, taking into consideration the close cooperation between authorities under the existing MLAT. Yet such an AMAA between the US and Canada has not been signed. Waller, above note 89 , at 373-74.

${ }^{108}$ Agreement between the Government of the United States and the Government of Australia on Mutual Antitrust Enforcement Assistance, 1999 U.S.T. LEXIS 198 (1999).

${ }^{109}$ Id. at Art. II(A).

${ }^{110} I d$. at Art. II(E).

${ }^{111}$ In this vein Chowdhury, above note 13,12 .

112 'Improving International Co-operation in Cartel Investigations. Contribution from Australia under Session II of the Global Forum on Competition', DAF/COMP/GF/WD(2012)36, paras 19-24 (24 January 2012), <http://www.oecd.org/officialdocuments/publicdisplaydocumentpdf/?cote=DAF/COMP/GF/WD\%282012\%2936\&d ocLanguage $=$ En>.
} 
judicial assistance (letters rogatory and letters of request ${ }^{113}$ ) which are not contingent in the US on reciprocity (although not all competition authorities are empowered to use them ${ }^{114}$ ). Thirdly, under the IAEAA's provisions parties retain discretion whether to offer assistance in particular cases. ${ }^{115}$ In 1997 Waller concluded that 'there is no reason to believe that the waiting line [to sign an agreement with the US under the IAEAA] will be very long ${ }^{116}$ and time proved him right.

Apart from these US-initiated agreements, there are two cases of inter-agency cooperation in other parts of the world: among the Nordic countries and between Australia and New Zealand. In the former case the Agreement Regarding Cooperation in Competition Cases was concluded in 2001 between Denmark, Iceland and Norway. ${ }^{117}$ In 2003 it was joined by Sweden. ${ }^{118}$ Article IV of the Agreement provides that the competition authorities of the Parties to the Agreement can exchange classified information, subject to the equivalent confidentiality protection in the receiving states, and only for competition law purposes. It is difficult to evaluate how robust is the cooperation under the Agreement. Article IV is most often invoked in cartel cases, but the Swedish Competition Authority has also exchanged information in merger cases with Finish and Norwegian counterparts, albeit no details were made public. ${ }^{119}$ Similarly, a common contribution concerning cooperation within the Nordic Cartel

\footnotetext{
${ }^{113}$ See generally OECD, Competition Law Enforcement. International Co-operation in the Collection of Information (Paris, 1984), Annex II: Explanatory Note on Letters Rogatory or Letters of Request.

${ }^{114}$ For example, it seems that the European Commission is not equipped with such a power as it is not provided for under the Regulation 1/2003, above n 32, or the Council Regulation (EC) No 139/2004 of 20 January 2004 on the Control of Concentrations between Undertakings (the EC Merger Regulation) OJ L 24, 1-22 (2004).

${ }^{115}$ Since Australia entered into the Agreement with the US, the Australian authorities must have considered it a beneficial step. Allan Asher, then the Acting Chairman of the Australian Competition and Consumer Commission noted that the Agreement will help the ACCC to address challenges posed by international cartels. He also pointed out that the Agreement would assist the Commission in dealing with the increasing numbers of mergers at the global level. ACCC, 'Gobal Enforcement Co-Operation', MR 047/99 (28 April 1999), <http://www.acc..gov.au/content/index.phtml/itemId/322854/fromItemId/378008?pageDefinitionItemId=16940>.

${ }^{116}$ In this vein Waller, above note 89 , at 378 .

${ }_{117}$ Reprinted in United Nations, Treaty Series, Vol. 2154, No.1-37613, 199 (2001).

${ }^{118}$ Agreement on Amendments and on Accession by Sweden to the Agreement between Denmark, Iceland and Norway Concerning Cooperation in Matters of Competitions, signed in Helsinki on 9 April 2003, reprinted in United Nations, Treaty Series, Vol. 2308, No. A-37613, 241 (2005).

${ }^{119}$ E-mails from Karin Lunning, Director of International Affairs at the Swedish Competition Authority of 26 and 31 January 2012 (on file with the author).
} 
Network (NCN, encompassing Denmark, Faroe Islands, Finland, Iceland, Norway, Sweden, and, from 2010, Greenland) indicated that confidential and sensitive information has been exchanged, but without providing any particulars. ${ }^{120}$ Such exchanges could take place either between the Nordic states which are members of the EU under Regulation 1/2003, or between parties to the 2001 Nordic Cooperation Agreement.

Apart from the proximity of competition laws, the members of the NCN point out to a number of extralegal factors facilitating their cooperation. These include cultural similarities, similarity of business communities (large MNCs often distinguish Nordic region from other parts of Europe and operate a common Nordic offices to run their business operations in the Nordic states), and low staff turnover in the agencies. ${ }^{121}$ This suggests that mutual understanding and trust are of great practical importance for advanced forms of inter-agency cooperation.

Similarly to the Nordic countries, Australia and New Zealand have many commonalities. In the legal sphere, New Zealand's competition law is modelled on Australian legislation. ${ }^{122}$ The close ties between both jurisdictions were further strengthened in 2007 by the adoption of a Cooperation Agreement, in which Parties committed themselves to use their best efforts to exchange and provide information. ${ }^{123}$ They acknowledged that it is 'in their common interest to share information, evidence and documentation' facilitating, inter alia, 'effective enforcement and promotion of

\footnotetext{
120 'The Nordic Cartel Network: A Regional Model for Cooperation between Cartel Units of Competition Authorities. Joint Contribution by Denmark the Faroe Islands, Finland, Greenland, Iceland, Norway and Sweden under Session II of the Global Forum on Competition', DAF/COMP/GF/WD(2012)34, para 12 (19 January 2012), <http://www.oecd.org/officialdocuments/publicdisplaydocumentpdf/?cote=DAF/COMP/GF/WD\%282012\%2934\&d ocLanguage $=$ En $>$.

${ }^{121} I d$. at para 6.

${ }^{122}$ See generally Allan Fels and Zaven Mardirossian, 'Cooperation, Comity, and Competition Policy in Australia' in Andrew T. Guzman (ed), Cooperation, Comity, and Competition Policy (Oxford: OUP, 2011) 180-81.

${ }^{123}$ Cooperation Agreement between the Australian Competition and Consumer Commission and the New Zealand Commerce Commission (2007), on file with the author, Art. 2.2.
} 
their respective competition, consumer and regulatory functions ${ }^{124}$ and 'coordination of investigations, prosecutions'. ${ }^{125}$ The Parties obliged themselves not only to maintain confidentiality of the information 'to the fullest extent possible', ${ }^{126}$ but also to 'use [their] best efforts to oppose ... any application by a third party ... for disclosure of such confidential information', ${ }^{127}$ directly addressing some of the popularly raised concerns regarding inter-agency information sharing. ${ }^{128}$ That said, the Agreement did not supersede domestic legislation. Hence to unravel the true scope for cooperation one needs to look into relevant rules in both states.

Under Section 155AAA of the Competition and Consumer Act $2010^{129}$ the Australian Competition and Consumer Commission (ACCC) has discretionary power to share confidential information with foreign counterparts, even if there is no special intergovernmental or inter-agency agreement in place. This is an important development, indicating that the concerns regarding inter-agency sharing of confidential information $^{130}$ can be successfully addressed. The New Zealand Commerce Commission (NZCC) has already utilized the Australian provision on several occasions. For example, in the 2010 Air Ambulance cartel case, investigated in both jurisdictions, the NZCC officially requested access to some of the confidential transcripts, which was granted by the ACCC, on certain conditions related to disclosure of such shared evidence. $^{131}$

\footnotetext{
${ }^{124}$ Id. at Art. 1.2(a).

${ }^{125}$ Id. at Art. 1.2(b).

${ }^{126}$ Id. at Art. 4.1.

${ }^{127}$ Id. at Art. 4.3.

${ }^{128}$ See above notes 23-24 and accompanying text.

${ }^{129}$ On 1 January 2011 the Competition and Consumer Act 2010 superseded the Trade Practices Act 1974. The discretionary powers of the ACCC to share information, introduced originally in 2007 under Section 155AAA, were not affected by this change.

${ }^{130}$ See above Part I

${ }^{131}$ Mary-Anne Borrowdale, 'Regional Co-operation- Moderator's Speaking Notes', ICN Cartel WorkshopMini-Plenary Session 1, paras 15-17 (2011), <http://www.comcom.govt.nz/assets/The-Commission/Speeches/ICNCartel-Workshop-Regional-Co-operation-speaking-notes-Mary-Anne-Borrowdale-11-October-2011.pdf>.
} 
The Australian—New Zealand relationship was initially asymmetrical. The situation begun to change with the passing of the Commerce (International Co-operation, and Fees) Amendment Act 2012. ${ }^{132}$ The Act authorizes the NZCC to provide investigative assistance to and to share confidential information (also compulsorily obtained) with foreign counterparts. It contains numerous safeguards, for example, ruling out cooperation if it was to harm New Zealand's international trade interests. ${ }^{133}$ It also prevents from sharing of any statements made to the NZCC, if that could lead to incrimination of the statements' author, unless the foreign counterpart provides written assurances that it will not happen. ${ }^{134}$ This new regulatory framework differs from the Australian regime, inter alia, by requiring that an intergovernmental or inter-agency agreement is in place prior to any such cooperation. ${ }^{135}$

Due to that later requirement and in order to balance out cooperation capacity in April 2013 the NZCC entered into new Cooperation Arrangement with the ACCC (without prejudice to the 2007 Cooperation Agreement). ${ }^{136}$ The Arrangement contains all the safeguards laid down in the recent New Zealand's legislation and it is so far the only one within that framework. ${ }^{137}$ It makes the bilateral cooperation more even. Rod Sims, the ACCC Chairman, rightly reflected that the Australian-New Zealand

\footnotetext{
${ }^{132}$ Commerce (International Co-operation, and Fees) Amendment Act 2012, Public Act 2012 No 84, date of assent 23 October 2012 < http://www.legislation.govt.nz/act/public/2012/0084/latest/096be8ed8097060d.pdf>.

${ }^{133}$ See Section 99I, newly added to the Commerce Act 1986.

134 The Act explicitly rules out both usage of such materials as evidence in foreign criminal proceedings as well as in proceedings leading to a pecuniary penalty 'or any equivalent proceedings'. The receiving agency is also required to ensure that such statements will not be used as evidence against the statements' author in such proceedings by other authorities (for example, in another, third jurisdiction). See Section 99J, newly added to the Commerce Act 1986.

135 Commerce Commission (International Co-operation, and Fees) Bill 2010: Briefing to the Commerce Committee on the equivalent Australian regime (2010), <http://www.parliament.nz/NR/rdonlyres/56239F5D-70794E0A-8220-73F7BC8D2F36/167352/49SCCO_ADV_00DBHOH_BILL8756_1_A68647_Briefingtothe.pdf>.

136 'Co-operation Agreement between the New Zealand Commerce Commission and the Australian Competition and Consumer Commission in relation to the Provision of Compulsorily-Acquired Information and Investigative Assistance', (2013), <http://www.comcom.govt.nz/dmsdocument/10032>.

${ }^{137}$ In October 2013 the NZCC published Guidelines on how requests for information in this framework will be dealt with. The Guidelines provide more transparency and signal preparedness to conclusion of further cooperation arrangements (since its simple unlikely that the NZCC would invest resources to prepare such general guidelines for the sake of the close New Zealand-Australia relationship). New Zealand Commerce Commission, 'Guidelines for Overseas Requests for Compulsorily Acquired Information and Investigative Assistance' (2013), <http://www.comcom.govt.nz/dmsdocument/11306>.
} 
relationship benefits from 'probably the most complete set of cooperation arrangements [in competition law]... globally, outside countries who have established cross border enforcers, such as the EU.' ${ }^{138}$

Both states not only allowed for greater cooperation between their competition authorities, but they also earlier bilaterally extended the jurisdictional scope of their domestic competition law provisions prohibiting abuse of the dominant position to the whole trans-Tasman market. This was also coupled with the introduction of provisions allowing for certain extraterritorial, or more accurately-trans-Tasman enforcement measures. In this regard under Section 155A of the Trade Practices Act the ACCC can require persons in New Zealand to provide documents or information in relation to possible abuse of a dominant position in a trans-Tasman market. The information may be provided to the NZCC, which would then pass it on to the ACCC. Importantly, it is an offence in New Zealand not to comply with such requests. Under the Section 155B of the Act reciprocal rights are provided to the NZCC. At the same time the ACCC cannot order a person in New Zealand to give evidence before it. It cannot also directly conduct enforcement activities in New Zealand. Moreover, in trans-Tasman competition cases an Australian court may, if that is more convenient or fair, conduct proceedings or deliver the judgment in New Zealand (the same applies the other way round). ${ }^{139}$

While this case of bilateral cooperation is exemplary, the unilateral approach of Australia deserves special attention and recognition. Section 155AAA of the Australian Competition and Consumer Act 2010, appears one of the most (if not the most) liberal legal frameworks worldwide governing evidence sharing. The ACCC can share

\footnotetext{
${ }^{138}$ Rod Sims, 'Closer Ties Across the Tasman' (Conference at the Victoria University, Wellington, 27 February 2013), <http://www.accc.gov.au/speech/closer-ties-across-the-tasman>.

${ }^{139}$ Brian Cassidy, 'Can Australian and US Competition Policy Be Harmonised?', presented at the conference 'An Australian/ US Free Trade Agreement-Opportunities and Challenges', 9-10 (Australian APEC Study Centre, Monash 2001), <www.apec.org.au/docs/Cassidy.pdf>. Compare Fels \& Mardirossian, above note 122Error! Bookmark not defined., at 180-81.
} 
confidential information, both provided to the ACCC in confidence or gathered by the authority itself, with 'a foreign government body' to assist it in its performance or execution of its functions. ${ }^{140}$ The notion of the foreign government body is defined broadly and it includes competition authorities irrespective of their character (administrative v. law enforcement agency) or their reach (regional, national, supranational). ${ }^{141}$ Since provisions of Section $155 \mathrm{AAA}$ do not require reciprocity as a precondition for disclosure, the ACCC may share confidential information with antitrust agencies which would not be able to offer comparable assistance. This type of national provisions allowing competition agency to share confidential information-without the consent of the source-with foreign counterparts are often called "information gateways". ${ }^{142}$

Upon a formal request from a foreign body it is up to the ACCC Chairman whether to disclose the information. ${ }^{143}$ The Chairman may 'impose conditions to be complied with in relation to protected information disclosed'. ${ }^{144}$ While the Section 155AAA itself does not list factors which should be considered, regard may be given to: ${ }^{145}$ (1) Australia's relations with other countries; (2) the need to avoid disruption to national and international law enforcement efforts; (3) the interests of the administration of justice; (4) the ACCC's policies, including its leniency programme; and (5) the effect that disclosure could have on the safety of an informant, as well as the fact that

\footnotetext{
140 Section 155AAA(12).

${ }^{141}$ Section 155AAA(21) defines 'foreign government body' as: '(a) the government of a foreign country; or (b) an agency or authority of a foreign country; or (c) the government of part of a foreign country; or (d) an agency or authority of part of a foreign country'. While there is no definition of the foreign country in this Section, it is provided that 'foreign country includes a region where: (a) the region is a colony, territory or protectorate of a foreign country; or (b) the region is part of a foreign country; or (c) the region is under the protection of a foreign country; or (d) a foreign country exercises jurisdiction or control over the region; or (e) a foreign country is responsible for the region's international relations.'

142 See, for example, International Enforcement Co-operation: Secretariat Report on the OECD/ICN Survey on International Enforcement Co-operation, above note 6, at 125.

143 Section 155AAA(12).

144 Section 155AAA(13).

145 Improving International Co-operation in Cartel Investigations. Contribution from Australia under Session II of the Global Forum on Competition, above note 112, at para 10.
} 
disclosure may discourage informants from providing information in the future. The later factor is reinforced in the ACCC's immunity policy. ${ }^{146}$ Except as required by law, ACCC will not share confidential information without informant's consent.

Australian authorities consider that sharing confidential information in assistance to foreign investigations 'benefits Australia as the effects of a cartel can often extend beyond a single country's borders. ${ }^{147}$ From this perspective Australia stands out as an example of a jurisdiction which not only managed to address concerns relating to confidential information sharing, but went beyond the limits of traditional public international law approach to international commitments by creating a framework allowing the ACCC to assist foreign counterparts in their investigations irrespective of whether they would be able to reciprocate.

Without getting involved in bilateral or plurilateral negotiations, Australia introduced a regime - an information gateway — which allows the ACCC to share confidential information with counterparts, on a case-by-case basis. This is a model solution. Australia-based entities considering anticompetitive strategies have good reasons to be alarmed. If the Australian example is followed, the international community could experience a radical improvement in the fight against transnational anticompetitive conduct (especially in cases where there is an international consensus as to the harmful nature of the conduct at stake). ${ }^{148}$

\footnotetext{
${ }^{146}$ Australian Competition and Consumer Commission, 'Immunity Policy for Cartel Conduct' (2011), <http://www.acc.gov.au/system/files/Immunity\%20policy\%20for\%20cartel\%20conduct\%20and\%20interpretation\% 20guidelines.pdf $>$, para 63.

${ }^{147} I d$. at para 11 .

148 Davies, the Head of the OECD Competition Division, cautions that in case of younger competition agencies introduction of information gateways might lessen business confidence in the treatment of confidential information by agencies in such jurisdictions. John Davies, 'Contribution to Roundtable on: Modalities and Procedures for International Cooperation in Competition Cases involving more than one Country' (UNCTAD 13th Session of the Intergovernmental Group of Experts on Competition Law and Policy, Geneva, 8-10 July 2013), 6, <http://www.unctad.org/meetings/en/Contribution/IGE2013_RT1_OECD_en.pdf $>$. This concern seems particularly valid with regard to potential impact on domestic leniency programs. That said, domestic legislation can rule out sharing of leniency materials to address this issue.
} 
Assisting foreign counterparts may of course absorb agency's scarce resources. This need not be a predicament to cooperation. There is no reason why the requesting agency should not be asked to cover the costs of assistance incurred by the requested authority. ${ }^{149}$ The recent New Zealand's legislation explicitly empowers the NZCC to request foreign counterparts to cover such costs. ${ }^{150}$

\section{CONCLUSIONS}

Despite increasingly transnational nature of commerce, competition laws remain predominantly national. Enforces often have to pursue foreign violators. In such transnational cases access to foreign-based evidence poses a great, frequently insurmountable, practical challenge. Most competition authorities are not empowered to share confidential information/ evidence with foreign counterparts, or assist them in that regard.

Various concerns are being voiced against such close inter-agency cooperation. As discussed, some of them are valid. Yet, none rule out confidential information sharing as such. This paper argued that necessary and appropriate safeguards can be introduced to accommodate legitimate worries. In some cases cooperation may not be possible, for example, due to important state interests involved. Given the harmful nature of anticompetitive conduct, such cases are an exception, not the rule.

Some states entered into international agreements allowing for inter-agency evidence/ confidential information sharing. These are welcomed developments, yet—as

\footnotetext{
149 Similar practice operates in the context of letters of request under Art. 14(2) of the Hague Evidence Convention Under. The state of execution (the requested state) may require reimbursement of 'fees paid to experts and interpreters and the costs occasioned by the use of a special procedure requested'. Hague Convention on Taking of Evidence Abroad in Civil or Commercial Matters (18 March 1970), <http://www.hcch.net/upload/conventions/txt20en.pdf>. Reprinted in Recueil des Conventions: 1951-2009 (Conférence de La Haye de Droit International Privé, 2009).

${ }^{150}$ Under Section 99J(1)(d) of the Commerce Act as amended by the Commerce (International Co-operation, and Fees) Amendment Act 2012, see above note 132.
} 
discussed - the scope of this phenomenon from a global perspective is limited. In most cases when the special regime explicitly allowing for disclosure has not been introduced, domestic laws governing confidentiality block any exchanges of confidential materials between the cooperation-oriented agencies.

Further efforts should be invested in building trust between competition law enforcers and further development of inter-agency enforcement cooperation. The Australian example, in particular, shows that suitable changes, allowing for close cooperation with foreign counterparts, can be introduced unilaterally. This model solution should be learnt from. Such a bottom-up change would be most welcomed. It would allow different states to adopt their own strategies, perhaps gradual, regarding information and evidence sharing. It could also create a political pressure for a change - a form of soft coercion-in these jurisdictions which are particularly concerned about confidential information sharing arrangements. If such approach is followed, the international community may experience a radical improvement in the fight against transnational anticompetitive conduct for the ultimate benefits of consumers. Since consumers in democratic countries cast votes, politicians should not easily disregard this opportunity. 